Женщина, особенно молодого возраста, ускоренно приобщалась к городским стандартам демографического поведения и жизни в целом. Это имело противоречивые последствия, одним из которых стала деградация семейных ценностей на селе. Все это способствовало формированию среди женщин отрицательного отношения к жизни в дальневосточных селах, закрепляло стереотипы о «вечной» отсталости деревни и в конечном счете усиливало нестабильность местного населения. Если пожилые сельчанки еще мирились с такой ситуацией, то молодежь реагировала на нее довольно болезненно, что проявлялось во все более усиливающемся оттоке из деревень региона.

\section{Список литературы:}

1. Возрастной состав населения Приморского края (по данным всесоюзной переписи 1979 г.). Владивосток: Краевое управление статистики, 1980. 142 с.

2. Российский государственный архив экономики (РГАЭ). Ф. 1562. Оп. 56. Д. 2736.

3. Проблемы демографического развития Сибири и Дальнего Востока: сб. науч. тр. / под ред. С.В. Соболевой. Новосибирск: Наука, 1991. 162 с.

4. Амурский статистический ежегодник. Благовещенск: Статуправление, 2008. 166 с.

5. Государственный архив Амурской области (ГААО). Ф. 480. ОП. 15. Д. 888.

6. Социально-экономические проблемы дальневосточного села. Владивосток: Дальнаука, 1987. 189 с.
7. Хабаровскому краю - 60 лет. 1938-1998. Хабаровск: Статуправление, 1998.98 с.

8. Решения партии и правительства по хозяйственным вопросам: сб. документов. Т. 14. М.: Политиздат, 1984. 703 с.

9. Постановление ЦК КПСС и Совета Министров СССР от 22.01.1981 г. «О мерах по усилению государственной помощи семьям, имеющим детей» [Электронный ресурс] // https://base.garant.ru/3999170.

10. Государственный архив Российской Федерации (ГАРФ). Ф. 374. Оп. 39. Д. 6189. Л. 136.

11. Женщины в Амурской области. Благовещенск: Статуправление, 1979. 54 с.

12. ГАРФ. Ф. 374. Оп. 39. Д. 6214. Л. 19.

13. Российский государственный архив социально-политической истории (РГАСПИ). Ф. 591. ОП. 1. Д. 127. Л. 32.

14. ГААО. Ф. 480. Оп. 12. Д. 142.

15. Геллер М.Я. Машина и винтики. История формирования советского человека. М.: МИК, 1994. 336 с.

16. Государственный архив Приморского края (ГАПК). Ф. П.-68. Оп. 50. Д. 429. Л. 48, 109.

17. Социально-экономический анализ уровня жизни населения Дальнего Востока / отв. ред. С.В. Югай. Владивосток: Дальнаука, 1989. 268 с.

18. Денисова Л.Н. Исчезающая деревня России: Нечерноземье в 1960-1980-е годы. М.: Институт российской истории РАН, 1996. 215 с.

19. РГАСПИ. Ф. 17. ОП. 153. Д. 1089.

\title{
THE POSITION OF WOMEN IN THE FAR EAST VILLAGES IN THE PERIOD OF «LATE» SOCIALISM
}

\section{(C) 2019}

Grinko Andrey Aleksandrovich, candidate of historical sciences, associate professor of Humanities Department Far Eastern State Agrarian University (Blagoveshchensk, Russian Federation)

Abstract. The paper analyzes the transformation of the female rural population position of the Far East in the USSR in 1970 - the first half of 1980 under the influence of a set of factors. The peculiarities of the geographical location of the region, its level of development, acceleration of life processes in rural areas, rapid dissemination of information and other factors had a significant impact on rural women. This influence was controversial and ambiguous. On the one hand, the role of a woman in the family changed, her activity as an employee increased, her wellbeing, cultural and educational level increased. On the other hand, becoming more independent, the woman aspired to better working and living conditions, career growth, free time increase, but in rural areas it was difficult. Despite the special attention of the state to the Far East and the activities aimed at the development of rural areas, life in the villages did not meet the «urban» views of local residents. The result of this transformation was a focus on childlessness for a large part of young people and moving to urban areas. Against the background of the village it was perceived as an incomparably better place of residence.

Keywords: USSR; Far East; rural area; «late» socialism; «developed» socialism; period of «stagnation»; women; family; urbanization; feminization; demographic situation; demographic behavior; fertility; life satisfaction; scarcity; level of well-being.

УДК 39

DOI 10.24411/2309-4370-2019-12229

Статья поступила в редакцию 11.02.2019

\section{ПЕРСПЕКТИВЫ РАЗВИТИЯ НАРОДНЫХ ХУДОЖЕСТВЕННЫХ ПРОМЫСЛОВ И РЕМЕСЕЛ НА ТЕРРИТОРИИ МОРДОВИИ}

(C) 2019

Кандрина Елена Владимировна, аспирант отдела этнографии и этнологии

Научно-исследовательский институт гуманитарных наук (2. Саранск, Российская Федерация)

Аннотащия. В данной статье на основе полевого материала автора, архивных документов и материалов, опубликованных рядом исследователей, проведен анализ состояния, перспектив и проблемных аспектов существования народных художественных промыслов и ремесел на территории Республики Мордовия на примере наиболее значимых традиционных мест их бытования. Проведен анализ трансформации понимания су- 
ти и структуры промысловой деятельности в рамках различных исторических этапов. Определены место, роль, особенности развития народных художественных промыслов и ремесел в условиях функционирования инновационной рыночной экономики. Рассмотрены основные формы художественно-ремесленной деятельности для получения дохода, в которых продолжают существовать промыслы. На современном этапе такие формы развиваются в семейных подрядах, династиях мастеров, среди индивидуальных предпринимателей, мастеров, занимающиеся каким-либо видом прикладного искусства помимо своей профессиональной деятельности. Обращено внимание на производство сувениров с национальной символикой, как особого вида изделий, в структуре народных промыслов. Кроме того, в статье отражены главные факторы, влияющие на состояние различных видов народных художественных промыслов и ремесел. Сформулированы основные положения, позволяющие повысить эффективность мер, направленных на возрождение, сохранение и развитие разнообразных видов традиционных народных художественных промыслов и ремесел на территории Мордовии.

Ключевые слова: кустарные промыслы; валяние; традиционная вышивка; вязание; лепка из глины; мордва; народные художественные промыслы; традиционный национальный костюм; резьба по дереву; ремесла; плетение из лозы; промысловая деятельность; сувениры; ткачество; традиционное место бытования промысла; хозяйственная деятельность; центр национальной культуры.

\section{Введение}

Промыслы издавна являлись частью хозяйственной деятельности народов, населявших территорию мордовского края. Производимые мастерами изделия обеспечивали не только бытовые потребности городского и сельского населения, позволяя повысить уровень дохода производителей, но и становились средством для реализации творческих способностей и задумок мастеров. Начиная с середины XIX века промыслы развивались повсеместно, особенно на территориях с бедными земельными ресурсами, и составляли значительную часть экономики региона, сохраняя лидирующие позиции вплоть до 30-х годов XX века [1, с. 94].

На современном этапе практически невозможно говорить о народных промыслах как о массовом производстве товаров и услуг, поскольку значительно изменилась сама структура индивидуальной трудовой деятельности, а также экономика страны в целом, в связи с чем многие виды промыслов потеряли свою актуальность и востребованность. С учетом современных реалий нормативно-правовые акты и государственные программы направлены на сохранение лишь отдельных видов промыслов в качестве культурного наследия прошлого. Современное осмысление промыслов подразумевает под этим понятием не традиционные промыслы как таковые, а народные художественные промыслы и ремесла. Их историко-культурное значение определено на федеральном уровне Законом «О народных художественных промыслах» [2], а также на уровне субъектов, например, Законом PM «O народных художественных промыслах и народных ремеслах в Республике Мордовия» [3, с. 5].

Следует отметить, что изделия, создаваемые мастерами, сегодня составляют лишь незначительную часть на рынке и реализуются в основном посредством участия в сельских, городских, республиканских выставках-ярмарках или выполнения неплановых индивидуальных заказов, чаще имеющих стихийный характер.

Если ранее промыслы были ориентированы на планируемое получение стабильного дохода, необходимого для жизни, то на современном этапе развития производства и рыночных отношений они приобретают особую культурную и историческую ценность. В каждом регионе бытования промысел имеет свою уникальную этническую окраску, специфику обращения с материалом, особую технологию обработки сырья, изготовления изделий и нанесения тра- диционной символики. Предметы материального мира, созданные мастерами-ремесленниками, хранят в себе историю и традиции народа, отражая самобытность и уникальность его культуры. Исходя из этого, объектом исследования данной статьи является состояние народных художественных промыслов и ремесел, рассматриваются формы их бытования на современном этапе, а также то, насколько сохранены традиционные способы обработки сырья и создания изделий на территории Мордовии.

\section{История, методология, цели и задачи исследования}

Промыслы издавна привлекали исследователей, изучавших данный вид деятельности как неотъемлемую часть хозяйственной деятельности, культуры и быта народа. Особого внимания по изучению различных видов промыслов среди населения мордовского края заслуживают работы И.И. Фирстова [4], в них дана классификация промыслов поволжского региона в зависимости от обрабатываемого сырья, также выделены местные и отхожие промыслы, их география и динамика с учетом этнического аспекта. Исследованию отдельных видов домашних ремесел и промыслов, таких как прядение, ткачество, плетение, а также значению их в экономике региона посвящены работы В.Н. Куклина [5; 6]. Особую значимость в рамках изучаемой тематики приобретают работы А.С. Лузгина [7-9], в которых автор детально анализирует крестьянские промыслы Мордовии, рассматривая их, с одной стороны, как составную часть хозяйственного уклада жизни, с другой - как элемент культуры этноса. Кроме того, автор дает материальнопространственную характеристику условий развития промыслов, их структуру, рынок промыслового труда и продукции. Особый интерес для исследования представляют работы Л.И. Никоновой [10-12], в которых подробно описаны особенности бытования ремесел и художественных занятий мордвы, проживающей не только на территории Мордовии, но и за ее пределами.

При проведении исследования были использованы следующие методы: историко-этнографический, системный, сравнительно-функциональный, метод анализа, экспедиционное полевое этнографическое исследование, в рамках которого посредством опроса, наблюдения, интервью был собран полевой материал автора.

Целью данной статьи является исследование перспектив развития народных художественных промыслов и ремесел на территории Мордовии. 
Для достижения поставленной цели необходимым представляется решение следующих задач:

- изучить трансформацию смыслового и структурного содержания понятия «промысел» на различных исторических этапах;

- определить роль и место народных художественных промыслов и ремесел в современном информационно-технократическом мире, основанном на законах инновационной рыночной экономики;

- исследовать основные формы бытования народных художественных промыслов и ремесел на территории республики на современном этапе;

- проанализировать возможные направления развития изучаемого вида деятельности как этнически традиционной составляющей для населения мордовского края.

\section{Анализ данных}

История развития промыслов включает в себя несколько этапов. До середины XIX века они являлись одним из видов хозяйственной деятельности, который осуществлялся в основном крестьянскими семьями. Результаты труда являлись благосостоянием всей семьи. Они включали предметы, изготовленные как для бытовых нужд семьи, так и на продажу. Реализуемые товары были дешевы и пользовались спросом в крестьянской и в мещанской среде [13, с. 46].

K концу XIX - началу XX века изделия промыслов все больше приобретают эксклюзивный характер и становятся дополнением к жизни, а не насущной необходимостью, у них появляется особый самобытный стиль, традиция выполнения предмета в сочетании с художественным талантом и вкусом мастера. Именно в это время зарождаются предпосылки к трансформации понимания сути промысла как явления. Ранее это был просто особый вид ручного производства: сначала частного, затем артельного, а потом и фабричного. С появлением в изделиях уникальности и единичности, относительно некоторых крестьянских промыслов появляется понятие «художественности», возникшее в конце XIX века в мастерских известного предпринимателя С.И. Мамонтова в подмосковном селе Абрамцево, которое закрепляется в искусствознании в советское время. В этот период зарождается разделение продукции ремесленников на промысловый товар массового потребления и товар, который обладает художественной ценностью как неповторимое единичное произведение. В связи с этим в советское время потребителями товаров народных художественных промыслов в основном становится интеллигенция как ценитель исконной многонациональной российской культуры, а для сельского быта данные предметы часто лишены практичности по сравнению с обыденными дешевыми предметами массового производства.

Современный этап развития промыслов преимущественно связан с их искусственным сохранением и возрождением в местах традиционного бытования как культурного наследия. Становится типичным, когда промысел включается в направление по развитию туристических программ. Очаги художественного творчества приобретают характер культурного бренда, выражая понятие «чем мы отличаемся от других народов». С другой стороны, создается новый экономический кластер как основа для формирования «креативной» экономики в сельской местности.
Деятельность, ориентированная на перспективы развития народных ремесел, позволит создавать новые рабочие места и развивать села республики.

Со сменой исторических формаций изменилось не только значение промыслов в жизнедеятельности людей, но и теоретическое осмысление данного явления. В нижеследующей таблице приведена, периодизация, отражающая смысловую и структурную трансформацию содержания промысловой деятельности на различных исторических этапах (табл. 1).

Примеры изменения значения и структуры промыслов на различных исторических этапах позволяют определить современные формы их бытования, к которым следует отнести: народные художественные промыслы, народные ремесла (данное понятие внесено отдельной статьей в отраслевой закон Республики Мордовия), сувениры. Однако следует отметить, что в современных описаниях сути промысла отсутствует указание на возможность реализации созданных мастерами изделий, в отличие от понимания основы данной деятельности на более ранних этапах.

Рассмотрим особенности бытования помыслов в рамках современных форм на примере отдельных видов народных художественных промыслов и ремесел Республики Мордовия.

На территории Мордовии, помимо описанных в таблице форм, сохранились занятия, имеющие черты кустарного промысла. Они выражены в мелкой семейной организации производства изделий для сбыта и являются поддержкой заработков. Данная продукция в основном сбывается скупщикам, реже непосредственно потребителям. Нередко эта форма на современном этапе развивается как семейный подряд. Так, например, в Теньгушевском районе изготовлением матрешки занимается около 50 мастеров, 25 из них работают семьями: муж осуществляет столярные работы по изготовлению формы, жена их расписывает. В своем исследовании профессор Л.И. Никонова отмечает, что результат ремесленного труда исстари принадлежал всей семье, за исключением мелочей (свадебных и др. подарков, предметов личной гигиены) $[17$, с. 33$]$.

Многие из мастеров в 1980-1990-х годах работали на Теньгушевском деревообрабатывающем комбинате, который являлся одним из основных предприятий в районе. Несмотря на то, что предприятие в годы перестройки было признано нерентабельным и впоследствии ликвидировано, мастера частично сохранили местную особенность сувенирной матрешки, основанную на стилистике росписи сел соседнего Вознесенского района Нижегородской области. Этим промыслом занимаются на дому мастера и сегодня, изготавливая многоместную и футлярную матрешку, токарную посуду и предметы быта (например, Ф.А. Даньшин (муж) и Л.И. Даньшина (жена), В.В. Куликова (сестра) и Н.В. Куликов (брат) и др.) [18].

Особого внимания в районе заслуживает промысел, развивающийся в рамках семейных династий. Здесь одним из ярких представителей столярного промысла является Д. Мазурик. Вместе с тестем И. Кузьмой он изготавливает столярную утварь: шкафчики-ключницы, деревянные шкатулки, ящички для визиток, оригинальные предметы для сервировки, к примеру, футляр-подставку для порционных чайных пакетиков, детские игровые конструкторы, 
Кандрина Е.В.

Перспективы развития народных художественных промыслов. .

07.00.00 - исторические науки и археология

которые затем в семье расписывают женщины. Ocoбенностью бытования данного занятия является то, что оно имеет все черты кустарного промысла, бытовавшего в конце XIX - начале XX веков: мастера

таблица 1 - Трансформация смыслового и струку таблорических этапах

\begin{tabular}{|c|c}
\hline Виды & \\
промысловой & Содержание \\
деятельности &
\end{tabular}

выполняют изделия на заказ и зависят напрямую от перекупщиков, которые поставляют им материал и отправляют полученный товар на рынки сбыта г. Вознесенска Нижегородской области и Москвы.

Конец XIX - начало XX века

\begin{tabular}{|c|c|}
\hline $\begin{array}{l}\text { омашние } \\
\text { омыслы }\end{array}$ & $\begin{array}{l}\text { - производство изделий в рамках домашнего хозяйства, для обеспечения семьи необходимы- } \\
\text { ми предметами быта; } \\
\text { - самостоятельная заготовка и переработка необходимого сырья; } \\
\text { - промысел является необходимой составляющей (обеспечительной частью) земледельческо- } \\
\text { го хозяйства и быта населения [14, с. 27]. }\end{array}$ \\
\hline $\begin{array}{l}\text { емесленные } \\
\text { ромыслы } \\
\text { ремесло } \\
\text { а заказ) }\end{array}$ & $\begin{array}{l}\text { - специализация некоторой части населения на отдельных видах деятельности (выработка } \\
\text { кож и овчин; деревообработка; бондарство, рогожно-кулевой и др.); } \\
\text { - тесная связь производства с натуральным хозяйством (сезонный характер деятельности); } \\
\text { - продукт труда ремесленника не является товаром, однако изделия выполняются не только } \\
\text { для нужд семьи, но и на заказ; } \\
\text { - ремесленники стоят в непосредственных личных отношениях с потребителями (покупате- } \\
\text { лями) [14, с. } 28] \text {. }\end{array}$ \\
\hline $\begin{array}{l}\text { рные } \\
\text { Іслы } \\
\text { ыслы }\end{array}$ & $\begin{array}{l}\text { - специализация труда на отдельном виде деятельности (деревообработка; кузнечное дело; } \\
\text { валяние; изготовление мебели и т.д.); } \\
\text { - базируется на частной собственности на средства производства и личном труде работника; } \\
\text { - производят изделия для широкого рынка потребления или продают свои произведения } \\
\text { скупщикам, которые забирали товар оптом; } \\
\text { - использование наемного труда в наиболее крупных производствах [14, с. 26-27]. }\end{array}$ \\
\hline & 60-е - начало 90 \\
\hline $\begin{array}{l}\text { Народные } \\
\text { художествен- } \\
\text { ные } \\
\text { промыслы }\end{array}$ & $\begin{array}{l}\text { - оригинальные, неповторимые произведения искусства, созданные индивидуально масте- } \\
\text { ром-художником; } \\
\text { - изделия приобретают статус произведения декоративно-прикладного искусства; } \\
\text { - представлены государственными специализированными предприятиями, объединяющими } \\
\text { несколько одинаковых или различных по художественному профилю производств, в соче- } \\
\text { тании с домашним художественным ремеслом (использование труда надомников с органи- } \\
\text { зацией поставок материалов и приема готовых изделий) [15, с. 7]. }\end{array}$ \\
\hline $\begin{array}{l}\text { уудо- } \\
\text { ель- } \\
\text { сфере } \\
\text { о- } \\
\text { нных }\end{array}$ & $\begin{array}{l}\text { - изготовление изделий для реализации, причем данного вида изделия могут производиться } \\
\text { соответствии с установленным порядком как по месту изготовления изделий, так и в други } \\
\text { городах и районах [16]. }\end{array}$ \\
\hline aя & $\begin{array}{l}\text { - памятный предмет, напоминающий о пребывании в том или ином месте (стране, городе, } \\
\text { республике, историческом месте, выставке); } \\
\text { - готовые изделия, художественно оформленные в традиционном характере республики, } \\
\text { края, области, отражающие национальные или местные особенности; } \\
\text { - механически воспроизведенный промышленностью в больших тиражах, созданный худож- } \\
\text { ником оригинал [15, с. 275]. }\end{array}$ \\
\hline \multicolumn{2}{|r|}{ Современный этап с начала (с начала 2000-х до настоящего момента) } \\
\hline $\begin{array}{l}\text { Народные } \\
\text { художествен- } \\
\text { ные } \\
\text { промыслы }\end{array}$ & $\begin{array}{l}\text { - одна из форм народного творчества, деятельность по созданию художественных изделий } \\
\text { утилитарного и (или) декоративного назначения, осуществляемая на основе коллективного } \\
\text { освоения и преемственного развития традиций народного искусства в определенной мест- } \\
\text { ности в процессе творческого ручного и (или) механизированного труда мастеров народ- } \\
\text { ных художественных промыслов [2]. }\end{array}$ \\
\hline ародные & $\begin{array}{l}\text { - самобытный вид деятельности, связанный с сохранением потомственных форм ручного } \\
\text { труда, наследуемого мастерства, базирующегося на традиционной культуре народов Рес- } \\
\text { публики Мордовия, то есть в конкретной определенной местности [3, с. 5]. }\end{array}$ \\
\hline Сувег & $\begin{array}{l}\text { - механически выполненные предметы, содержащие знаковую информацию о месте пребы- } \\
\text { вания (тарелки, бокалы, магниты и пр.); } \\
\text { - куклы в национальных костюмах разной степени этнической достоверности; } \\
\text { - художественно оформленные предметы с элементами национального орнамента. }\end{array}$ \\
\hline
\end{tabular}


Особое место в Теньгушевском районе занимает вязальный промысел - традиционная «теньгушевская семицветка», которая давно находит своего ценителя и покупателя не только в нашей республике, но и за ее пределами. Мастера данного вида промысла также зависят от заказов и тех людей, которые покупая изделия оптом, помогают реализовать их за пределами региона. В Мордовии же сбыт вязаных изделий из Теньгушева имеет стихийный характер. Мастера могут реализовать свои изделия, участвуя в районных или региональных фестивалях, национальных праздниках, выставках-ярмарках, а это свидетельствует о том, что стихийность предложения не формирует стабильного спроса на промысловые изделия хорошего качества, традиционного по смысловому наполнению, приемлемой ценовой категории, практичных, закладывающих правильный образ национальной культуры и колорита [18].

Исследование Теньгушевского района позволяет констатировать, что на данной территории из традиционных промысловых занятий: вязания, столярного дела, валяния, плетения корзин из лозы - лидирующую позицию занимают сувенирные формы. Матрешки, грибки-копилки, свистульки, кухонные скалки, емкости для сыпучих продуктов, бочонки для меда имеют роспись различного качества - от профессиональных приемов иконописной техники темперной росписи до росписи акриловыми красками. Район можно действительно признать уникальным ареалом бытования разнообразных видов традиционных народных художественных промыслов, ремесел, в том числе прижившегося и развивающегося на исследуемой территории сувенирного промысла, однако центром объединения мастеров является не населенный пункт Мордовии, а город Вознесенск соседней Нижегородской области, поскольку именно оттуда поступает большее количество заказов [18]. Это указывает на необходимость доработки республиканских программ и законодательных актов по поддержке и сохранению народных художественных промыслов и ремесел на местах в части грамотного выстраивания экономики данного видов деятельности.

Образцом сохранения отхожего промысла в Мордовии является валяльный промысел села Урусово Ардатовского района. Для территории этот вид является традиционным, поскольку еще в XIX столетии здесь занимались валянием. В.Н. Куклин отмечал его характер как кустарный, т.к. мастера уходили в отход далеко за пределы своего места проживания [19, с. 161]. В настоящее время урусовские мастера продолжают делать валенки не только для жителей мордовского края, но и для представителей других регионов нашей страны. Традиционными местами отхода для урусовских валяльщиков, по словам Ю.А. Аксенова, считались Башкирия, Оренбургская и Самарская области, которые сохранились еще с дедовских времен. Ассортимент изделий достаточно широк и представлен: валенками детскими и взрослыми, чесанками, домашними валенками. Наиболее известными мастерами являются Н.А. Юртаев, Н.А. Понятов, А.В. Маторкин, Н.М. Лукин, Г.Н. Потешкин, а также династии мастеров: И.С. (отец) и Г.И. Старчков (сын); М.П. Борисов (отец), С.М. Борисов (сын), В.С. Борисов (внук); А.С. Кудашов (отец), М.А. Кудашов (сын), В.А. Кудашов (сын) [20, с. 15].
Несмотря на технический прогресс, технология изготовления валенок практически не изменилась, однако появилось такое направление, как художественное оформление валенок вышивкой и нанесение орнамента в технике сухого валяния [20, с. 14] (Такие валенки можно встретить среди изделий семейного подряда Аксеновых, декоративную отделку выполняет жена мастера Н.М. Аксенова).

На сегодняшний день с. Урусово является положительным примером сохранения и развития валяльного промысла. Прежде всего это связано с тем, что традиция предков передана по наследству и на современном этапе продолжает сохранять самобытную технологию производства в ее первоначальном виде. Кроме того, каждый мастер имеет свою целевую группу потребителей и стабильные точки сбыта. Особое значение для дальнейшего развития промысла является включение с. Урусово в туристические маршруты по Мордовии, что позволит привлечь туристов, повысить доход и мотивацию мастеров, а также интерес к данному виду промысла как у населения, так и государственных структур. Однако для повышения спроса у потребителей необходимо совершенствование уровня художественного, дизайнерского оформления изделий. С этой целью необходима организация обучения мастеров применению в декоре техники сухого валяния, вышивки с использованием этнического компонента и этнографических орнаментальных образцов, проведения мастерклассов с приглашением профессиональных художников и специалистов.

Уникальным примером зарождения, развития и бытования нового вида национальной резьбы по дереву сувенирного характера является с. Подлесная Тавла Кочкуровского района. В 70-е годы XX века эта территория становится центром объединения мастеров-резчиков, когда небольшая группа молодых сельских умельцев сплотилась вокруг самобытного художника, педагога, заслуженного работника культуры РФ Н.И. Мастина [21, с. 2]. Базой для обучения ремеслу была экспериментальная детская художественная школа, ученики которой впоследствии сами становились мастерами. Школа стала уникальной творческой лабораторией, где сельских ребятишек обучали не только техникам резьбы, но и пониманию особенностей и уникальности эрзянской культуры, особенностей жизненного уклада, что ярко выражено в сюжетах резной игрушки.

Тавлинская резьба стала заметным явлением художественных выставок в республике и за ее пределами, предметом коллекционирования. В 80-е годы $\mathrm{XX}$ века творения народных умельцев из эрзянского села пополнили ассортимент сувенирной продукции, выпускавшейся в Мордовии. Однако положительный опыт школы, направленный на подготовку мастеров для народного художественного промысла, к сожалению, не поддерживался реалиями жизни, ведь промысел может существовать только тогда, когда предложение поддерживается спросом. Кроме того, проблемы возникали и с организацией рабочих мест для выпускников, их заработком и поиском потенциальных рынков сбыта изделий. Попыткой решения проблемы стало создание в 1989 году кооператива «Тавлинский сувенир», основная деятельность которого была направлена на сохранение тавлинского 
феномена. После перестройки в 1999 году был создан Союз тавлинских мастеров «Эрьмезь», в состав которого вошло 15 наиболее талантливых мастеров под руководством Петра Владимировича Рябова. Основными задачами союза было возрождение эрзянской национальной культуры, сохранение и развитие народных художественных, этнических и духовных традиций посредством института наставничества, выставочной деятельности, экскурсионных туров, проведения семинаров и мастер-классов, участия в региональных фестивалях, выставках-ярмарках. Кроме того, учитывая прошлый опыт, союз предусматривал экономическую составляющую промысла, определяя несколько направлений его развития: прежде всего, это создание узнаваемых и уникальных скульптур малых форм и деревянной игрушки; ландшафтной скульптуры, используемой для оформления детских городков, окраин сел, родников, обрядовых мероприятий; бытовых утилитарных вещей (предметов домашней утвари); национальных музыкальных шумовых инструментов.

В итоге плодотворной работы с учетом комплекса факторов, являющихся залогом успешного развития промыслов, изделия тавлинских мастеров признаны не только в Мордовии, но и среди родственных финно-угорских народов (экспонаты получили высокие экспертные оценки на выставках в Эстонии, Удмуртии, Марий Эл, Республике Коми).

Анализируя сегодняшнее состояние промысловой деятельности резчиков с. Подлесная Тавла Кочкуровского района, следует отметить, что изделия являются уникальными по художественному замыслу и технике исполнения, они отражают и сохраняют самобытные традиции эрзянского народа в рамках данной локальной территории; здесь существует традиция наставничества. С целью развития этого направления ведется выставочная и экскурсионная деятельность, осуществляются работы по изготовлению изделий на заказ - все это характеризует тавлинскую резьбу как промысел в традиционном его понимании. Однако вопрос сбыта изделий остается проблемным аспектом развития промысла, поскольку носит стихийный характер: реализация осуществляется в рамках выставок-ярмарок, при выполнении специальных частных и региональных заказов, что, несомненно, осложняет участь бытования промысла. Положительной тенденцией для разрешения данной проблемы стало включение в 2018 году села Подлесная Тавла в туристический маршрут как места традиционного бытования уникального промысла [22]. Немаловажным фактором дальнейшего развития уникального промысла является участие Союза в грантах. Так, например, средства, полученные благодаря победе в конкурсе проектов «Культурная мозаика малых городов и сел», позволили организовать межрегиональный фестиваль «Раськень Ойме» («Душа народная»). На территории села был заложен «Этно-парк». Кроме того, с целью повышения туристической привлекательности данной территории из Фонда Елены и Геннадия Тимченко было выделено 2 млн руб. на развитие направления этно-арт в оформлении села Подлесная Тавла [23]. Однако вопрос сбыта, поиска потенциальных точек для реализации изделий мастеров на современном этапе по-прежнему имеет весомое значение для дальнейшего развития тавлинской резьбы.
На протяжении истории развития тавлинского феномена в программу экспериментальной художественной школы вводились предметы для организации мастерской для девочек. Предпочтение было отдано работе с местным сырьем - глиной, которую с давнего времени крестьяне села использовали при строительстве саманных домов, а также в изготовлении лепных большеформатных горшков. Педагогами было найдено самобытное направление работы в керамике. Здесь особого внимания заслуживает уникальные по своему содержанию пластические композиции из глины, стилистика которых была разработана еще в 1990-х годах Гаушевой Лидией Ивановной, педагогом экспериментальной художественной школы с. Подлесная Тавла. Ее сказочная скульптура - это образец рождения в глине этнокультурного образа, узнаваемого и художественно ценного. К сожалению, после ухода мастера на заслуженный отдых созданный в селе очаг самобытной керамики обнаруживает тенденцию к угасанию, поскольку его особенность заключалась не только в мастерстве конкретного человека, но и в особом материале (местной глине), добываемом самим промысловиком. Изделия из глины также остаются приоритетным направлением для тавлинский школы мастеров, однако необходим комплексный подход для того, чтобы выработанная стилистическая традиция сохранилась.

Как показывают реалии жизни, перспективной формой для сохранения и поддержки народных художественных промыслов и ремесел является организация центров народной культуры на территориях их традиционного бытования. Одним из таких центров в республике является образованный в 1992 году Мокшанский центр национальной культуры в селе Старая Теризморга Старошайговского района. Благодаря этому народный художественный промысел, имеющий глубокие корни, развивается особым образом. Так, на базе центра функционируют: этнографический музей, детский ансамбль «Лаймоня», Старотеризморгский народный хор, кружки по народной вышивке и плетению бисером [24]. Сочетание фольклорных и прикладных аспектов позволяет воссоздавать этнографически выверенные образцы вышивки, национальных украшений и декоративных частей костюма. Мастерицы знают традицию раскроя и технологию вышивки, основу нанесения орнамента нескольких вариантов мокшанского костюма, которые воссоздаются на основе сохранившихся еще от бабушек элементов костюмного комплекса, характерного для данной местности, а это свидетельствует о том, что для создания центра было правильно выбрано место - там, где традиция жива в сознании носителей культуры. Кроме того, промысел обеспечивает обрядовые традиции, сохраненные на территории и активно развивающиеся на современном этапе.

Мастерицами села Старая Теризморга выполняются на заказ вышитые полотенца, национальные рубахи для проведений свадебных обрядов, национальных праздников. На основе традиционной вышивки, характерной для данной локальной территории, возникла современная интерпретация национальной вышивки села Лемдяй, создательницей которой является Бикеева Мария Ивановна. Благодаря ее деятельному творчеству, сегодня несколько ма- 
стериц села развивают это направление как народный художественный промысел, поскольку изделия пользуются спросом и находят своего покупателя [25].

Безусловно, положительный опыт Мокшанского центра национальной культуры демонстрирует значительный потенциал, который имеют творческие люди нашей республики, но залогом подобных успехов являются не только сплоченная работа коллектива единомышленников и умелое руководство лидера, но и программы систематической государственной поддержки, эффективный менеджмент, организация востребованных туристических маршрутов.

Своеобразным индикатором художественного мастерства в области народных ремесел является ежегодный республиканский фестиваль народного творчества «Шумбрат, Мордовия!». Анализируя материалы выставок за последние десятилетие, которые представляют районные коллективы, можно составить картину наиболее перспективных на сегодняшний день видов народного творчества и мастеров, владеющих ремеслами [26].

Одним из популярных традиционных ремесел является плетение из лозы и лыка. В данном виде творчества работают многие мастера: в г. Саранске (М.Ю. Олькин), г. Рузаевка (С.С. Глухов, А.Д. Митрошин), с. Ичалки (П.М. Ганичев, Г.И. Ситникова), г. Краснослободске (А.А. Тимченко), с. Сабаево Кочкуровского района (Т.И. Цыпкайкина, Н.Ф. Бигачева), с. Новое Качаево Большеигнатовского района (А.В. Мусин) [26].

Отметим, что незаменимые в прошлом в быту вещи и сейчас пользуются спросом - корзины приобретаются как в качестве утилитарного предмета быта, так и элемента декора. Лапти зачастую выполняются мастерами в качестве сувениров, домашней или банной обуви, а также для воссоздания костюмных комплексов танцевальных и фольклорных коллективов республики. Однако объемы продаж невелики, а спрос имеет стихийный характер, что вынуждает мастеров нередко оставлять ремесло в поисках средства к существованию.

Излюбленным материалом мастерового человека является дерево. Выставки показывают, что практически в каждом районе интерес к этому материалу высокий, но работа с деревом не только требует умения выполнять резьбу в объеме или на плоскости, также важно понимание природной красоты материала и умение завершать отделку (обработку) изделия. Поэтому к разряду профессионального мастерства можно отнести небольшой процент экспонировавшихся работ. Среди них произведения резчиков из с. Подлесная Тавла (Е.Г. Миронов, Д.А. Гаушев). Опираясь на стилистику тавлинской резьбы, ищут свое направление резчики с. Большие Березники (Д.А. Архипов, А.С. Никонов). Особого внимания заслуживают работы мастера с. Большое Игнатово А.И. Смирнова, работающего в направлении традиционного ложкарного промысла. В его коллекции работ ложки соседствуют с токарной посудой, изящными декоративными ковшами. По запросам рынка работают современные бондари. Постоянный участник республиканских выставок-ярмарок А.А. Уваров из с. Редкодубье Ардатовского района совершенствует ассортимент винных бочек, банных принадлежностей, ищет несложные приемы декора выжиганием. Ак- тивно представляет бондарное ремесло мастер с. Большие Березники О.В. Буров, предлагая разные форматы бытовых и винных бочек, шайки для бани. Таким образом, деятельность резчиков сочетает работу с предметами утилитарного и сувенирного характера.

Наряду с деревянными изделиями одним из приоритетных материалов становится керамика, которая широко представлена на выставках декоративноприкладного искусства последних лет. Интерес к работе с глиной связан с организацией мастерской при Институте национальной культуры МГУ им. Н.П. Огарева под руководством художника и педагога С.С. Борисовой. Среди изделий гончаров особой популярностью пользуется различной формы посуда, выполненная в традиционном крестьянском стиле (Е.В. Панькин - с. Ичалки; А.П. Русяев - г. Саранск). На сегодняшний день предпринимается попытка возродить гончарное ремесло в селе Шишкеево Рузаевского района, где создана мастерская и приобретено оборудование на средства президентского гранта.

Из-за сложности технического оснащения и трудности подготовки сырья мастера редко представляют на выставках республики некогда бытовавшие традиционные изделия, такие как глиняная свистулька. К самобытным чертам древней окарины можно отнести стиль свистулек педагога из города Ардатов И.Ф. Уряднова. К созданию лепной свистульки обращались педагоги детских художественных школ с. Подлесная Тавла Кочкуровского района и Рузаевки. Однако, как вид ремесла, традиция создания глиняных игрушек в народном, этническом стиле утрачена.

Особым направлением трансформации народных художественных промыслов и ремесел в современных реалиях является создание сувениров, которые становятся наиболее интересным приобретением для туристов. Особенностью качественного сувенира является его относительная дешевизна в сочетании с этнически достоверным исполнением с использованием в их стилистике традиционных материалов, национальных цветов, орнамента. Сувенир - это некое напоминание о стране или регионе пребывания, поэтому он должен быть уникален по своей сути. Таким примером сувенира, имеющим свой узнаваемый стиль, являются работы мастериц из Ковылкинского и Инсарского районов. Будучи потомственными носителями народной культуры, они создают кукол в традиционных мокшанских костюмах, типичных для своего села. Художник из города Рузаевка С.Ф. Сараева выполняет сувенирную куклу на деревянной основе, в полотняной одежде с украшением мокшанской и эрзянской ручной счетной вышивкой. Узнаваемый почерк имеют сувенирные куклы в стилизованных мордовских костюмах рузаевской мастерицы О.Т. Буйновой.

Таким образом, анализ исследования материалов ежегодных выставок республиканского фестиваля «Шумбрат, Мордовия!» показывает, что в республике накоплен значительный потенциал для развития ремесел, основанных на использовании местного сырья, характерных форм с привлечением исконного народного стиля и традиционных особенностей декора. Имеют тенденцию развития формы бытовых ремесел и сувенира. Определенное влияние на уровень мастерства оказывают профессиональные учебные заведения. Следует отметить, что мастера, рабо- 
ты которых отличаются особым художественным вкусом с сохранением традиционных элементов, являются потенциальным ядром для развития сектора уникальной сувенирной продукции в качестве бренда региона.

\section{Заключение}

В заключение следует отметить, что вследствие смены исторических формаций, изменения структуры государственного устройства и экономической деятельности, развития технологий трансформировалось понимание сути промысловой деятельности. Так, из деятельности, которая была дополнительной к основному хозяйству, обеспечивающей бытовые нужды и приносящей добавочный заработок, промыслы приобретают специфику декоративно-прикладного искусства, а создаваемые изделия - художественное оформление.

Помимо традиционных мест бытования промыслы распространяются и на другие территории, мастера начинают использовать не только местный материал, но и привозную шерсть, глину, ткань и нити фабричного производства. Кроме того, под влиянием моды и изделий, создаваемых профессиональными художниками, изменяется вид и орнаментация традиционных объектов материального мира, появляются сувенирные формы.

Также существенно изменяется экономическая и культурная составляющая промысла. Типично, что мастерство в основном не передается по наследству, как это было в традиции народа, ему обучают, используя художественные каноны в учебных заведениях. Занятие народными художественными ремеслами для мастеров на современном этапе является в основном средством выражения своих художественных и творческих способностей, нежели возможностью повысить свое благосостояние.

Следует отметить, что многие виды традиционных для территории мордовского края промыслов на современном этапе продолжают бытовать в основном в рамках современных форм ремесел. Так, к народным художественным промыслам можно отнести опирающиеся на традиции национальной культуры следующие виды творчества: резьбу по дереву, гончарные изделия, вышивку, вязание, ткачество, изготовление украшений из бисера. Ремесленный характер имеют: плетение из лыка и ивового прута, бондарство. К сувенирной форме тяготеют: глиняная игрушка, куклы в традиционном костюме, изготовление деревянных игрушек, матрешек. Особое значение имеет валяльный промысел, поскольку на современном этапе он сохранил черты традиционного отхожего промысла, а также токарно-столярный, coхраняющий черты традиционного кустарного промысла.

Особого внимания на сегодняшний день заслуживает вопрос, связанный с сохранением, возрождением и популяризацией народных художественных промыслов и ремесел как на региональном, так и на федеральном уровнях. С целью повышения эффективности действий, направленных на разрешение обозначенной проблемы, необходим комплексный подход, включающий систему следующих мер:

- Всестороннее государственное содействие, в том числе финансовое (разработка государственных, программ, грантов, направленных на поддержку и развитие народных художественных промыслов и ремесел, совершенствование навыков мастеров).
- Грамотное выстраивание туристических маршрутов на основе традиционных центров бытования промыслов, поскольку там, где бытует промысел, сохраняются уникальные самобытные традиции народа.

- Создание единого республиканского ремесленного центра - Ассоциации мастеров, который позволит осуществлять планирование и контроль деятельности в области традиционных ремесел, а также объединить в своей структуре районные центры национальной культуры и ремесел, очаги бытования промыслов и отдельных мастеров. Исторический опыт подсказывает, что только при коллективном объединении в местах бытования народных промыслов возможно сохранение традиционных технологий, применение местных материалов, совершенствование приемов труда. Мастеру-одиночке это не по плечу, поскольку он может лишь имитировать традиционные ремесла, зачастую смешивая традиции при создании изделия.

- Создание эффективной системы управления, которая позволит не только координировать работу центров народной культуры и ремесел, но и структурировать возможные точки сбыта производимых мастерами изделий.

Кроме того, для улучшения состояния в области развития народных художественных промыслов и ремесел необходима детальная проработка следующих аспектов:

- создание районных ремесленных центров, в первую очередь в местах сохранения и бытования ремесел и промыслов (в районах, где есть потомственные носители культуры, которые могут передать культурный код в вышивке, ткачестве, ковке, резьбе по дереву, работе с глиняной, воссоздании комплекса национального костюма и т.д.);

- выработка собственной неповторимой, узнаваемой, информативной стилистики изделий, которая позволит сформировать «правильный» спрос у покупателей;

- повышение художественного качества выполняемых мастерами изделий;

- повышение эффективности деятельности самих мастеров (формирование навыков самопрезентации и презентации своего промысла; правильного ценообразования; умения работы с Интернет-ресурсами с целью популяризации и сбыта изделий);

- повышение уровня знаний об истории, истоках и исконных традициях промысловой деятельности в рамках отдельно взятой местности; участие в выставках-ярмарках).

Подводя итог, необходимо отметить, что уровень бытования и развития народных художественных промыслов и ремесел в районах Республики Мордовия различен. На территориях, где сохранены исторические очаги бытования промыслов, проживают носители культуры и сохранились традиции обработки сырья и создания тех или иных хозяйственных предметов или предметов быта, народные художественные промыслы живут и продолжают развиваться, находя своего ценителя и покупателя. К таким территориям относятся: с. Старая Теризморга Старошайговского района, с. Урусово Ардатовского района, с. Подлесная Тавла Кочкуровского района, с. Теньгушево Теньгушевского района, с. Редкодубье Ардатовского района, г. Рузаевка и др. Однако существуют районы, где традиционные народные худо- 
жественные промыслы и ремесла необходимо восстанавливать, создавая благоприятные условия для их возрождения. К таким территориям, например, можно отнести Темниковский, Ковылкинский, Краснослободский, Атяшевский районы и др. Предусмотренные автором меры могут быть включены в комплекс мер по повышению привлекательности сельской местности, созданию новых рабочих мест в районах республики, развитию туризма и программ, направленных на сохранение и развитие традиционных народных художественных промыслов и ремесел мордовского края.

\section{Список литературы:}

1. Лузгин А.С. Народные промыслы мордовского края. Вторая половина XIX - начало XX в. (этнокультурные аспекты). Саранск: Мордов. кн. изд-во, 2016. $272 \mathrm{c}$

2. О народных художественных промыслах: Федеральный закон от 6 января 1999 г. № 7-Ф3; по состоянию на: 29 июля 2017 г. [Электронный ресурс] // Собрание законодательства Российской Федерации: официальные электронные версии бюллетеней // http://szrf.ru/szrf/doc.phtml?nb=100\&issid=1002017031 $000 \&$ docid $=57$.

3. О народных художественных промыслах и народных ремеслах в Республике Мордовия: Закон Республики Мордовия от 14 июня 2000 г. № 28-3; по состоянию на: 08 декабря 2003 г. // Известия Мордовии. 16 июня 2000. № 103 (22.361).

4. Фирстов И.И. Отхожие кустарные промыслы мордовского пореформенного крестьянства // Труды НИЯЛИЭ. Вып. 62. Саранск: Мордов. кн. изд-во, 1978. С. 99-127.

5. Куклин В.Н. Домашнее производство и промыслы сельского населения мордовской АССР // Краеведение Мордовии: мат-лы I-й мордовской краевед. конф. / ред. И.Е. Автайкин [и др.]. Саранск: Мордовское книжное издательство, 1973. С. 175-180.

6. Куклин В.Н. Изготовление плетеной обуви у мордвы в XIX - начале XX в. // Исследования по археологии и этнографии Мордовской АССР: Труды. Вып. 39 / под ред. П.П. Коровина, Т.М. Фролкиной. Саранск: Мордов. кн. изд-во, 1970. С. 142-160.

7. Лузгин А.С. Промыслы Мордовии. Саранск: Мордовское книжное издательство, 1993. 142 с.

8. Лузгин А.С. Жизнь промыслов: промысловая деятельность крестьян Мордовии во второй половине XIX - начале XX в. (этнокультурные аспекты). Изд. 2-е, доп. Саранск: Мордов. кн. изд-во, 2007. 228 с.

9. Лузгин А.С. Народные промыслы Мордовского края: вторая половина XIX - начало XX в. (этнокультурные аспекты). Саранск: Мордов. кн. изд-во, 2016. 269 c.

10. Никонова Л.И., Щанкина Л.Н., Шерстобитова Ж.В. Мордва Западной Сибири: монография: в 2 ч. / под ред. В.А. Юрченкова. Саранск: Научно-исследовательский институт гуманитарных наук при Правительстве Республики Мордовия, 2009. 109 с.

11. Никонова Л.И., Щанкина Л.Н., Гармаева Т.В. Мордва Циркумбайкальского региона и Республики Хакасия: монография / под ред. В.А. Юрченкова, Л.И. Никоновой. Саранск: НИИ гуманитарных наук при Правительстве Республики Мордовия, 2010. 265 с.

12. Никонова Л.И. Мордва Саратовской области: монография / под ред. В.А. Юрченкова, Л.И. Нико- новой. Саранск: Научно-исследовательский институт гуманитарных наук при Правительстве Республики Мордовия, 2013. 251 с.

13. Никонова Л.И. Народы Мордовии: историкоэтногр. исследования / под ред. д-ра ист. наук, проф. В.А. Юрченкова, д-ра ист. наук, проф. Л.И. Никоновой. Саранск: НИИ гуманитар. наук при Правительстве Республики Мордовия, 2012. 608 с.

14. Фирстов И.И. Основные виды кустарных промыслов в пореформенной Мордовии // Материальная и духовная культура мордвы в XVIII-XX вв. Труды НИЯЛИЭ. Вып. 62. Саранск: Мордов. кн. изд-во, 1978. C. $25-58$.

15. Бардина Р.А. Изделия народных художественных промыслов и сувениры (Товароведение и организация торговли): учеб. пособ. для проф.-техн. учеб. заведений. Изд. 2-е перераб. и доп. М.: Высшая школа, 1977.312 с.

16. Об индивидуальной трудовой деятельности: Закон СССР от 19.11.1986 г. (ред. от 14.03.1988, с изм. от 25.12.1990) // Свод законов СССР. 1990. Т. 2. СТ. 12.

17. Никонова Л.И., Кандрина И.А., Щанкина Л.Н. Традиционная культура сохранения здоровья народов, проживающих в Республике Мордовия: историко-этнографический аспект: монография / под ред. дра ист. наук, проф. В.А. Юрченкова, д-ра ист. наук, проф. Л.И. Никоновой. Саранск: НИИ гуманитар. наук при Правительстве Республики Мордовия; Пенза: Научно-издательский центр «Социосфера», 2010. 528 с.

18. Полевой материал автора (ПМА), собранный автором в рамках реализации проекта «Мордовия Мастеровая», 2019 год, Теньгушевский район Республики Мордовия.

19. Куклин В.Н. Домашние производства и ремесла мордвы в XIX - начале XX в.: дис. ... канд. ист. наук. Саранск, 1968. 265 с.

20. Лузгин А.С. Урусовские валенки: метод. пособие по валке. Саранск: Морд. кн. изд-во, 2008. 19 с.

21. Шибаков Н.И. Мастера из Подлесной Тавлы. Саранск: Мордов. кн. изд-во, 1983. 84 с.

22. Об утверждении плана мероприятий («дорожной карты») по сохранению, возрождению и развитию народных художественных промыслов и ремесел в Республике Мордовия на период 2018-2020 годов: Приказ Министерства культуры, национальной политики, туризма и архивного дела Республики Мордовия № 122 от 4 мая 2018 года [Электронный pecypc] // Официальный портал органов государственной власти Республики Мордовия. - http://emordovia.ru/mkh/otkrytye-dannye/normativnye-akty/ teksty-proektov/ministerstvo-kultury-i-turizma-rm.

23. Культурная мозаика малых городов и сёл [Электронный pecypc] // http://cultmosaic.ru/winners/ podlesnaya-tavla-etno-art-territoriya/?back_url=/contests/ kulturnaya-mozaika-partnerskaya-set/winers.

24. Центр национальной культуры в с. Старая Теризморга [Электронный ресурс] // Туристско-информационный центр Республики Мордовия // https:// turizmrm.ru/what-to-visit/culture/museums/moksha-culture.

25. ПМА: Фестиваль «Шумбрат - 2018».

26. Дом народного творчества: Фестиваль «Шумбрат, Мордовия!» 2007-2018 [Электронный ресурс] // Дом народного творчества Республики Мордовия. http://rdnt13.ru/meropriyatiya/shumbrat-mordoviya. 


\title{
THE STATE OF THE CRAFT ACTIVITY ON THE TERRITORY OF MORDOVIA (AT THE PRESENT STAGE)
}

(C) 2019

Kandrina Elena Vladimirovna, postgraduate student of Ethnography and Ethnology Department Humanities Research Institute (Saransk, Russian Federation)

\begin{abstract}
In the following paper the author analyzes the state, prospects and problematic aspects of folk arts and crafts existence in the Republic of Mordovia on the examples of the most significant traditional places of their existence. The author uses her own field data analysis as well as archival documents and researchers' materials. The author analyzes transformation of the understanding of the essence and structure of fishing activity in the framework of various historical stages. The place, role, features of folk arts and crafts development in the conditions of an innovative market economy are determined. The main forms of arts and crafts activities for income generation, in which crafts continue to exist are considered. At the present stage, such forms are developed in family contracts, dynasties of craftsmen, among self-employed persons, craftsmen engaged in some kind of applied arts and crafts besides their professional activities. Attention is paid to the production of souvenirs with national symbols as a special type of products in the structure of folk crafts. The paper reflects the main factors which have an effect on the state of various kinds of folk arts and crafts. The fundamental principles that allow to increase the effectiveness of measures aimed at reviving, preserving and developing various types of traditional folk arts and crafts on the territory of Mordovia are formulated.

Keywords: handicrafts; wallow; traditional embroidery; knitting; clay crafting; Mordovia; national artistic trades; traditional national dress; wood carving; crafts; wickerwork; trade; souvenirs; weaving; traditional place of trade existence; economic activity; center of national culture.
\end{abstract}

УДК 9.93/94

DOI 10.24411/2309-4370-2019-12230

Статья поступила в редакцию 04.02.2019

\section{ПРАВОВОЕ ГОСУДАРСТВО И «ГОСУДАРСТВО ПРАВДЫ» В РАБОТАХ М.В. ШАХМАТОВА}

(C) 2019

Быстрюков Владимир Юрьевич, кандидат исторических наук,

доцент кафедры всеобщей истории, права и методики обучения

Самарский государственный социально-педагогический университет (2. Самара, Российская Федераџия)

Аннотация. В начале 1920-х х гг. в русской эмиграции возникло евразийское движение. Его представители пытались объяснить причины русской революции, по-новому оценив исторический путь развития страны и ее культурные особенности. В первой половине 1920-х гг. движение громко заявило о себе и быстро набирало популярность в среде русской интеллигенции. Его лидеры стали привлекать к публикации в евразийских изданиях новых авторов, среди которых оказался выпускник юридического факультета Петербургского университета Мстислав Вячеславович Шахматов. В евразийских изданиях он опубликовал только две статьи. Однако его роль и значение в евразийском движении в современной историографии оцениваются кардинально различно: от причисления к основателям евразийства до отрицания какой-либо значимой роли в его истории. В своих работах, опубликованных в Евразийских Временниках, М.В. Шахматов рассматривал особенности идеально-государственной доктрины древнерусских княжеств и Московского царства на основе летописей и других произведений древнерусской письменности. М.В. Шахматов считал, что право по содержанию сверхсознательно и вытекает из религиозных предпосылок, из правды Божией. Эти идеалы древнерусские люди распространяли на область государственно-правовых явлений. По его мнению, государство ставило себе три главные задачи: блюстительство православия, водворение правды на земле и защиту лишь в общих чертах физического существования народа. «Идея «подвигоположничества» верховной власти из ранней истории христианства пришла в Византию и особую остроту приобрела на Руси. Своего полного выражения «идеально-государственная» доктрина подвига власти достигла в XVI в. М.В. Шахматов отмечал, что политическая реальность жизни древнерусских княжеств и вечевых городов сильно отличалась от идеалов, заложенных в летописях и других произведениях древнерусской письменности. Однако идеал «государства правды» сохранился в трудах славянофилов, Ф.М. Достоевского, П.И. Новгородцева, а также его отдельных проявлениях в практике Российской империи.

Ключевые слова: Русская эмиграция; евразийское движение; М.В. Шахматов; П.Н. Савицкий; Н.С. Трубецкой; Н.Н. Алексеев; Россия-Евразия; «Евразийский временник»; «государство правды»; закон; естественное право; правовое государство; подвиг верховной власти; православие.

Евразийское движение, возникшее в начале 1920х гг. в эмиграции, привлекло в свои ряды достаточно большое количество русских интеллектуалов, представителей различных отраслей знания. Для многих из них участие в движении (в основном заключавшееся в публикации текстов в евразийских изданиях и участии в публичных дискуссиях и диспутах) было только определенным этапом в жизни и творчестве. Можно назвать лишь несколько человек, чья дея- тельность в 1920-30-ее гг., то есть во время существования движения, было связано с евразийством. Ключевой фигурой являлся П.Н. Савицкий, стоявший у его истоков, возглавивший его после «кламарского раскола» и реанимировавший движение в 1930-е гг. В 1920-е гг. идейным лидером считался князь Н.С. Трубецкой, чья брошюра «Европа и человечество» считается первым евразийским текстом [1]. После скандала с Трестом и «кламарского раско- 